\title{
Immunoglobulin G Subclass 4 Measurement
}

National Cancer Institute

\section{Source}

National Cancer Institute. Immunoglobulin G Subclass 4 Measurement. NCI Thesaurus.

Code C122130.

The determination of the amount of immunoglobulin $\mathrm{G}$ subclass 4 present in a sample. 